UDC 334.021:658:69.009

DOI: https://doi.org/10.32782/2415-8801/2020-1.19

Velychko Volodymyr PhD, Assistant,

O.M. Beketov National University of Urban Economy in Kharkiv

Grytskov Evgen

PhD, Associate Professor,

O.M. Beketov National University of Urban Economy in Kharkiv

Zubarev Dmitriy

Graduate Student,

O.M. Beketov National University of Urban Economy in Kharkiv

\title{
STAKEHOLDERS OF CONSTRUCTION ENTERPRISES: AREAS AND FEATURES OF INTERACTION
}

The aim of the study is to determine the directions and characteristics of interaction with stakeholders of construction enterprises. The types of stakeholders of construction enterprises are determined. a methodological approach to an integrated assessment of the level of stakeholder relations of construction enterprises is proposed, which creates a quantitative basis for developing a stakeholder-oriented strategy for their management and making managerial decisions aimed at increasing investment attractiveness. As a result of the assessment, an integral indicator of the level of stakeholder relations of construction enterprises has been determined. The proposed measures to increase the efficiency of the formation and implementation of contractual relations, the interaction of stakeholders in the areas of functioning of construction enterprises, the formation and implementation of corporate governance in the system of relations between interested parties, strategic directions, the formation and implementation of socio-economic and innovative directions in interaction with interested parties.

Keywords: stakeholders, construction enterprises, level of stakeholder relations, methodological approach, assessment of the level of stakeholder relations.

\section{СТЕЙКХОЛДЕРИ БУДІВЕЛЬНИХ ПІДПРИСМСТВ: НАПРЯМИ ТА ОСОБЛИВОСТІ ВЗАЕМОДІї}

Величко В.А., Грицьков С.В., Зубарєв Д.В.

Доведено необхідість виявлення особливостей та розробках напрямів взаємодії стейкхолдерів будівельних підприємств, розробка шляхів ефективності їх взаємовідносин, щңо створить підгрунтя для збільщення рівня інвестиційної привабливості та розвиток будівельних підприємств. Метою дослідження є визначення напрямів та особливостей взаємодії із стейкхолдерами будівельних підприємств. Для досягнення поставленої мети вирішуються наступні завдання: визначення стейкхолдерів будівельних підприємств; формування оцінного підгрунтя для виявлення особливостей щцодо забезпечення взаємодӥ із стейкхолдерами; розробка заходів підвищення ефективності взаємодії із зацікавленими особами. Визначені види стейкхолдерів будівельних підприємств. запропоновано методологічний підхід до інтегральної оцінки рівня стейкхолдерних відносин будівельних підприємств, який створює кількісне підгрунтя для розробки стейкхолдерно-оріснтованої стратегї̈ їх управління та прийняття управлінських рішень спрямованих на зростання інвестиційної привабливості. Методологічний підхід до інтегральної оцінки рівня стейкхолдерних відносин включає сукупність взаємопов'язаних етапів, що забезпечують формування інформаційно-аналітичного забезпечення щцодо взаємодії стейкхолдерів, здійснення оцінних процедур та розробки висновків щцодо результатів оцінки рівня стейкхолдерних відносин у контексті формування стейкхолдерно-орієнтованої стратегії управління будівельними підприємствами. У результаті оцінки визначено інтегральний показник рівня стейкхолдерних відносин будівельних підприємств, який дозволяє встановити, щңо на найбільшим значенням цього критерію характеризувалось АT «ХК «Київміськбуд». Запропоновані заходи щңодо зростання ефективності формування та реалізації договірних відносин, взаємодії стейкхолдерів за сферами функціонування будівельних підприємств, формування та реалізації корпоративного управління у системі взаємовідносин міэс зацікавленими особами, стратегічних напрямів, формування та реалізації соціально-економічного та інноваційного напрямів при взаємодії із зацікавленими особами, створення системи формування та визначення показників стратегічного стану будівельних підприсмств, забезпечення їх перманентного моніторингу.

Ключові слова: стейкхолдери, будівельні підприємства, рівень стейкхолдерних відносин, методологічний підхід, оцінка рівня стейкхолдерних відносин. 


\section{СТЕЙКХОЛДЕРЫ СТРОИТЕЛЬНЫХ ПРЕДПРИЯТИЙ: НАПРАВЛЕНИЯ И ОСОБЕННОСТИ ВЗАИМОДЕЙСТВИЯ}

Величко В.А., Грицьков Е.В., Зубарев Д.В.

Целью исследования является определение направлений и особенностей взаимодействия со стейкхолдерами строительных предприятий. Определены виды стейкхолдеров строительных предприятий. Предложен методологическийподходкинтегральнойоценкиуровнястейкхолдерныхотноченийстроительныхпредприятий, который формирует количественное основание для разработки стейкхолдерно-ориентированной стратегии их управления и принятия управленческих решений направленных на рост инвестиционной привлекательности. В результате оценки определен интегральный показатель уровня стейкхолдерных отношений строительных предприятий. Предложенны меры относительно роста эффективности формирования и реализации договорных отношений, взаимодействия стейкхолдеров по сферам функционирования строительных предприятий, формирования и реализации корпоративного управления в системе взаимоотношений.междузаинтересованными лицами, стратегических направлений, формирования и реализации социально-экономического и инновационного направлений при взаимодействии с заинтересованными лицами.

Ключевые слова: стейкхолдеры, строительные предприятия, уровень стейкхолдерных отночений, методологический подход, оценка уровня стейкхолдерньх отношений.

Introduction. Construction enterprises affect the functioning of other areas of the state economy and ensure their development. Along with this, the current state of the construction industry is characterized by ambiguity and a high level of turbulence. In particular, over eight years, the growth of the construction products index has slowed down by $11,5 \%$, in 2018 , compared with the previous year, the volumes of residential buildings commissioned for use decreased by $17,4 \%$, and apartments built by $30,2 \%$. At the same time, there is an increase in the volume index of completed construction work and a decrease in the level of construction in progress.

In such conditions, the identification of features and the development of areas of interaction among stakeholders of construction enterprises, the development of ways of the effectiveness of their relationships is of particular importance. This will create the basis for increasing the level of investment attractiveness and development of construction enterprises. So, the research topic is relevant, and its development is important for the functioning of construction enterprises.

Analysis of existing research. Domestic and foreign scientists: R. Ackoff [1-3], A. Ammar [4], P. Dunselmi [5], T. Donaldson and L. Preston [6], were engaged in solving the problems of forming and ensuring interaction with stakeholders. Cleland [7], K. Mamonov [8], T. Momot [9], A. Mendelow [10], N. Popova [11], E. Freeman [12], etc.

The aim of the study is to determine the directions and characteristics of interaction with stakeholders of construction enterprises.

The objectives of the study. To achieve this goal, the following tasks are solved:

- determination of stakeholders of construction enterprises;

- the formation of an assessment basis for identifying features to ensure interaction with stakeholders;

- development of measures to improve the effectiveness of interaction with stakeholders.

Main part. To ensure stakeholder relations, their types are determined. Summarizing the existing legal framework for certain types of stakeholders:

1. State authorities: The Verkhovna Rada of Ukraine, the Cabinet of Ministers of Ukraine, the Verkhovna Rada of the Autonomous Republic of Crimea, the Council of Ministers of the Autonomous Republic of Crimea, the central executive body that ensures the formation of state policy in the field of urban development, the central executive body that implements state policy in the field of urban development, central executive authority implementing state policy on issues of state architecture and construction control and supervision, bodies of state architectural and construction control, other authorized bodies of urban planning and architecture, local state administrations, local authorities.

2. Bodies of state architectural and construction control structural units on issues of state architectural and construction control of Kiev and Sevastopol city state administrations; executive bodies on issues of state architectural and construction control of village, town, city councils.

3. State bodies providing the development and implementation of urban planning documentation.

4. The bodies for the formation of the urban cadastre.

5. Bodies providing the formation and use of land.

6. Subjects of architectural activity.

7. Social Security Authorities.

8. Bodies responsible for the liability of enterprises, their associations, institutions and organizations for violations in the field of urban development.

9. Bodies providing reconstruction of housing stock.

10. Authorities performing design and technical supervision during the construction of an architectural object.

11. Bodies authorized to consider cases of violations in the field of urban development.

12. Domestic stakeholders engaged in investment activities in the construction industry.

13. Stakeholders providing the implementation of scientific and technical activities in construction.

14. Contractor.

15. Subjects providing innovative activity.

16. Customer.

17. Financial and credit institutions.

18. Organizations providing interaction with construction companies in the field of securities transactions.

19. Audit companies that exercise external and internal control over the financial and economic activities of construction enterprises.

20. Insurance organizations and companies that interact with construction companies.

21. Steak holders forming and realizing foreign investments. 
22. Bodies providing external control over the activities of construction enterprises.

23. Workers.

24. Corporate governance bodies.

25. Founders of construction enterprises.

26. Top management.

27. Leaders of different levels.

28. Other stakeholders.

The formation and implementation of stakeholder interaction is based on a quantitative basis, which requires the development of a methodological approach to an integrated assessment of the level of stakeholder relations. In the presented approach, a set of methods is used: analytical, expert, method of analyzing hierarchies, identifying anomalies of the first and second levels. Local and integral models are used to evaluate indicators in a multi-level system for determining the level of stakeholder relations.

The development of a methodological approach to the integrated assessment of the level of stakeholder relations of construction enterprises includes the following interrelated stages:

- the formation of information and analytical support for the interaction of stakeholders of construction enterprises;

- building a multi-level system of factors of integrated assessment of the level of stakeholder relations;

- determination of factors of the third level in the integrated assessment system;

- development of models for determining system factors of the second level;

- assessment of system factors of the second level of a multilevel system;

- building an integrated assessment model;

- assessment of weight coefficients of mutual influence and the impact of system factors on an integral indicator of the level of stakeholder relations;

- determination of the integral indicator of the level of stakeholder relations of construction enterprises;

- development of conclusions based on the assessment of the level of stakeholder relations in the context of the formation of a stakeholder-oriented strategy for managing construction enterprises.

The development of a methodological approach to the integrated assessment of the level of stakeholder relations of construction enterprises is carried out in accordance with and is the basis for the formation of a stakeholderoriented management strategy.

According to certain stages, it should be noted that the formation of information and analytical support regarding the interaction of stakeholders of construction enterprises (SIAZ) is carried out using:

- Statistical Information (SI)

- information on the formation and implementation of contractual relations between stakeholders (SDZ)

- accounting data (SB) (SDS)

- Information of the State Statistics Service of Ukraine

- Stakeholder Engagement Initial Information (SPS)

- information on the formation and implementation of corporate relations of construction enterprises (SKV)

- information relations formation and implementation of strategic directions of the functioning of building relations $(\mathrm{SSN})$.
In general, the model for the formation of information and analytical support regarding the interaction of stakeholders of construction enterprises has the following form:

$$
S I A Z=\langle S I, S D Z, S B, S D S, S P S, S K V, S S N, \Omega\rangle,
$$

$\Omega$ - many relations and connections between the directions of formation of information and analytical support regarding the interaction of stakeholders of construction enterprises.

The construction of a multi-level system of factors of integrated assessment of the level of stakeholder relations includes three levels:

Level 3: includes local factors that are determined on the basis of analytical and expert methods;

Level 2: formed from system factors, which are determined by the corresponding models.

In general terms, models for determining systemic factors affecting the level of formation and implementation of stakeholder relations of construction enterprises are as follows:

$$
\begin{aligned}
& S_{1}=\sqrt[n]{\prod_{i=0}^{10} S_{1 j}} \\
& S_{2}=\sqrt[n]{\prod_{i=0}^{10} S_{2 j}} \\
& S_{3}=\sqrt[n]{\prod_{i=0}^{10} S_{3 j}} \\
& S_{4}=\sqrt[n]{\prod_{i=0}^{10} S_{4 j}} \\
& S_{5}=\sqrt[n]{\prod_{i=0}^{10} S_{5 j}} \\
& S_{6}=\sqrt[n]{\prod_{i=0}^{10} S_{6 j}},
\end{aligned}
$$

$S_{1}, S_{2}, S_{3}, S_{4}, S_{5}, S_{6}$ - systemic factors of quality and the level of fulfillment of contractual obligations, the level of interaction of the studied construction enterprises with various groups of stakeholders; the formation and implementation of corporate governance of construction enterprises to ensure interaction with stakeholders; that provides interaction of stakeholders in the context of the formation and implementation of strategic directions of the functioning of construction enterprises; which determines the socio-economic and innovative level of construction enterprises, which are provided through the interaction of stakeholders; strategic state of construction enterprises, rel. units;

$S_{1 j}, S_{2 j}, S_{3 j}, S_{4 j}, S_{5 j}, S_{6 j}-$ local factors of the level of stakeholder relations, rel. units;

$n$ - the number of factors that formulate systemic indicators of the level of stakeholder relations of construction enterprises, rel. units;

$i$ - the importance of factors forming systemic indicators of the level of stakeholder relations of construction enterprises, rel. units;

$j$ - factor number, rel. units.

To assess the integral indicator of the level of stakeholder relations, the values of system factors are applied and weight coefficients are determined using the hierarchy analysis method, which includes the following steps: 
1. Definition of experts determining the mutual and general influence of system factors on the integral indicator of the level of stakeholder relations of construction enterprises.

2. Taking into account the results of the assessment of systemic factors in the level of stakeholder relations.

3. Pairwise assessment of the impact of system factors by experts.

4. Pairwise comparison of systemic factors of the level of stakeholder relations of construction enterprises on the T. Saati scale.

5. Building a matrix for assessing systemic factors in the level of stakeholder relations by construction enterprises. Matrices are developed for each investigated construction company.

$$
A_{I_{5}}=\left[\begin{array}{cccccc}
1 & S_{1} / S_{2} & S_{1} / S_{3} & S_{1} / S_{4} & S_{1} / S_{5} & S_{1} / S_{6} \\
S_{2} / S_{1} & 1 & S_{2} / S_{3} & S_{2} / S_{4} & S_{2} / S_{5} & S_{2} / S_{6} \\
S_{3} / S_{1} & S_{3} / S_{2} & 1 & S_{3} / S_{4} & S_{3} / S_{5} & S_{3} / S_{6} \\
S_{4} / S_{1} & S_{4} / S_{2} & S_{4} / S_{3} & 1 & S_{4} / S_{5} & S_{4} / S_{6} \\
S_{5} / S_{1} & S_{5} / S_{2} & S_{5} / S_{3} & S_{5} / S_{4} & 1 & S_{5} / S_{6} \\
S_{6} / S_{1} & S_{6} / S_{2} & S_{6} / S_{3} & S_{6} / S_{4} & S_{6} / S_{5} & 1
\end{array}\right],
$$

6. Defining eigenvector components $K_{S_{i}}$ for indicators of the level of stakeholder relations.

7. Determination of weight coefficients of the mutual influence of system factors and their influence $\left(k_{s_{i}}\right)$ on an integral indicator of the level of stakeholder relations of construction enterprises:

$$
k_{S_{i}}=\frac{K_{S_{i}}}{\sum_{i=0}^{n} K_{S_{i}}} .
$$

At the last stage, conclusions are drawn up based on the results of assessing the level of stakeholder relations in the context of forming a stakeholder-oriented strategy for managing construction enterprises. In this case, methods of economic and mathematical modeling are used that determine the influence of system factors on the integral indicator of the level of stakeholder relations of construction enterprises.

Summarizing the foregoing, a scheme has been developed for the formation of a methodological approach to the integrated assessment of the level of stakeholder relations of construction enterprises (Fig. 1).

Using the proposed approach, an integral indicator of the level of stakeholder relations of construction enter-

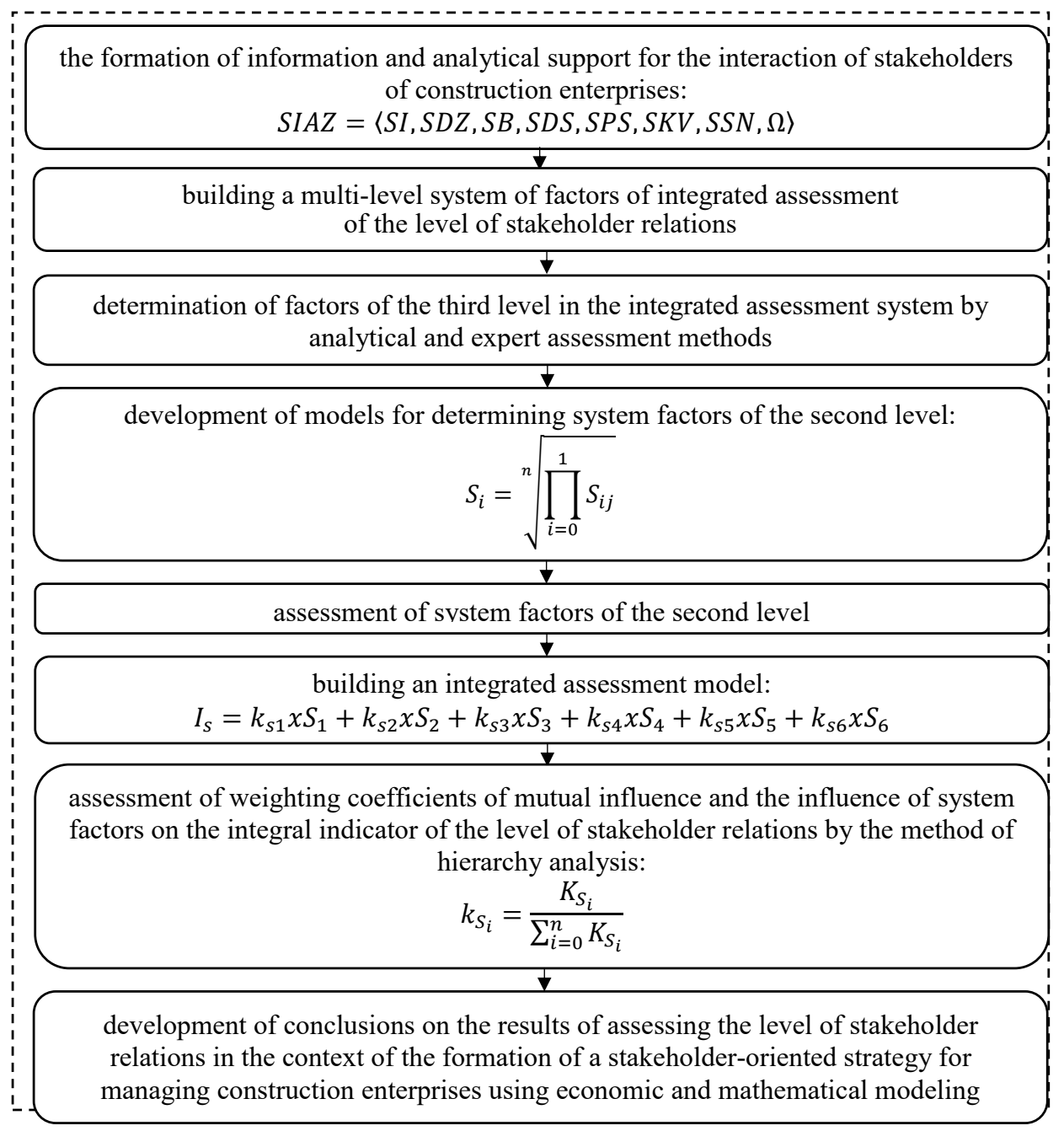

Fig. 1. The development scheme of a methodological approach to the integrated assessment of the level of stakeholder relations of construction enterprises 
prises is determined $\left(I_{s}\right)$ : JSC "HC "Kievgorstroy"- 5.84; OJSC "Brovarskoy zavod stroitel'nykh konstruktsiy" 4.85; KDSK JSC - 4.97; JSC "Trest Zhilstroy-1" - 4.96; Construction Company Mis'kzhitlobud LLC - 4.39; Real Estate Capital CJSC - 4.8; "Zhilstroy-2" LLC - 4.82; Ukrainian State Construction Corporation "UkrBud" 4.9; The construction group "Fundament" - 4.82 .

Conclusion. Thus, as a result of the study, a methodological approach to an integrated assessment of the level of stakeholder relations of construction enterprises was proposed, which creates a quantitative basis for developing a stakeholder-oriented strategy for their management and making managerial decisions aimed at increasing investment attractiveness. The methodological approach includes a system of factors that take into account the quality and level of fulfillment of contractual obligations, the directions and characteristics of the interaction of the studied construction enterprises with various groups of stakeholders, the formation and implementation of corporate management of construction enterprises to ensure interac- tion with stakeholders, strategic areas of functioning and their state, social and economic and innovative level of construction enterprises.

As a result of the assessment, an integral indicator of the level of stakeholder relations of construction enterprises has been determined, which allows us to establish that JSC "HC "Kievgorstroy" was characterized by the highest value of this criterion. However, as at other construction enterprises, it was determined by a moderate level, which requires measures to increase the effectiveness of the formation and implementation of contractual relations, the interaction of stakeholders in the areas of functioning of construction enterprises, the formation and implementation of corporate governance in the system of relationships between interested parties, strategic directions, the formation and implementation of socioeconomic and innovative areas in cooperation with stakeholders, with building a formation system and determining indicators of the strategic state of construction enterprises, ensuring their permanent monitoring.

\section{References:}

1. Akoff R. (1972) Planirovanie v bolshikh ekonomicheskikh sistemakh [Planning in large economies]. Moskow: Sovetskoe radio. (in Russian)

2. Akoff R., Emeri F. (1974) O czeleustremlyonnykh sistemakh [About purposeful systems]. Moskow: Sovetskoe radio. (in Russian)

3. Akoff R. (1982) Iskusstvo resheniya problem [The art of problem solving]. Moskow: Mir. (in Russian)

4. Ammari A. O. (2012) Klasyfikatsiia steykkholderiv na osnovi vzaiemnykh ochikuvan [Stakeholder classification based on mutual expectations]. Aktualni problemy ekonomiky. 8, 150-155. [in Ukrainian]

5. D’Anselmi P. (2011) Values and Stakeholders in an Era of Social Responsibility. New York, p. 27.

6. Donaldson T., Preston L. (1997) The Stakeholder Theory of the Corporation: Concepts, Evidence, and Implications. Academy of Management Review. 1, 65-66.

7. Klilend D. (2004) Upravlenie zainteresovannymi liczami proekta [Project stakeholder management]. Moskow, 73-91.

8. Mamonov K. A. (2013) Steykkholderna stratehiia vartisno-oriientovanoho upravlinnia kapitalom brendu budivelnykh korporatyvnykh pidpryiemstv [Stakeholder strategy for value-oriented brand management of construction corporate enterprises] (Ph.D Thesis), Kharkiv, 557.

9. Momot T. V., Filatova I. O., Konoplina O. O. Steikkholderno-orientovanyi pidkhid do zabezpechennia finansovoekonomichnoi bezpeky pidpryiemstv: teoretyko-metodychni zasady vprovadzhennia [A stakeholder-oriented approach to ensuring financial and economic security of enterprises: theoretical and methodological principles of implementation]. Ekonomichna teoriia ta istoriia ekonomichnoi dumky. Avaitable at: https://www.google.com/url? sa=t\&rct=j\&q=\&esrc=s $\&$ source $=$ web\&cd $=2 \&$ cad $=($ accessed 01.02 .2020$)$.

10. Mendelow A. L. (2008) Information Systems Planning: Incentives for Effective Action. Graduate School of Management, Kent State University, USA. 245-254.

11. Popova N. V. (2016) Marketynh steikkholderiv: teoretychni aspekty ta problemy vprovadzhennia [Stakeholder marketing: theoretical aspects and implementation issues]. Visnyk sotsialno-ekonomichnykh doslidzhen, 1 (60), 169-178. Avaitable at: http://vsed.oneu.edu.ua/collections/2016/60/pdf/169-178.pdf (accessed 02.02.2020).

12. Freeman E. (1984) Strategic Management: A Stakeholder Approach. Pitman, Boston p. 34

\section{Список використаних джерел:}

1. Акофф Р. Планирование в больших экономических системах / пер. с англ. Г.Б. Рубальского / под ред. И.А. Ушакова. Москва : Советское радио, 1972. 223 с.

2. Акофф Р., Эмери Ф. О целеустремлённых системах / пер. с англ. / под ред. И. А. Ушакова. Москва : Советское радио, 1974. 272 с.

3. Акофф Р. Искусство решения проблем / пер. с англ. / под ред. Е.Г. Коваленко. Москва : Мир, 1982. 224 с.

4. Аммарі А.О. Класифікація стейкхолдерів на основі взаємних очікувань. Актуальні проблеми економіки. 2012. № 8. C. 150-155.

5. D’Anselmi P. Values and Stakeholders in an Era of Social Responsibility, Free Press, New York, NY, 2011 , p. 27.

6. Donaldson T., Preston L. The Stakeholder Theory of the Corporation: Concepts, Evidence, and Implications. Academy of Management Review, 1997. №. 1, pp. 65-66.

7. Клилэнд Д. Управление заинтересованными лицами проекта / под ред. Дж. К. Пинто / пер. с англ. под ред. В.Н. Фунтова. Москва, 2004. Ч. 1. Гл. 4. С. 73-91.

8. Мамонов К.А. Стейкхолдерна стратегія вартісно-орієнтованого управління капіталом бренду будівельних корпоративних підприємств : дис... д-ра екон. наук: 08.00.04. Харків, 2013. 557 с. 
9. Момот Т.В., Філатова І.О., Конопліна О.О. Стейкхолдерно-орієнтований підхід до забезпечення фінансовоекономічної безпеки підприємств: теоретико-методичні засади впровадження. Економічна теорія та історія економічної думки. URL: https:/www.google.com/url?sa=t\&rct=j\&q=\&esrc=s\&source=web\&cd=2\&cad= (дата звернення: 01.02.2020).

10. Mendelow A.L. Information Systems Planning: Incentives for Effective Action. Graduate School of Management, Kent State University, USA. 2008, pp. 245-254.

11. Попова Н В. Маркетинг стейкхолдерів: теоретичні аспекти та проблеми впровадження. Вісник соиіальноекономічних досліджень. 2016. Випуск 1 (60). C. 169-178. URL: http://vsed.oneu.edu.ua/collections/2016/60/ pdf/169-178.pdf (дата звернення: 02.02.2020).

12. Freeman E. Strategic Management: A Stakeholder Approach. Pitman, Boston. 1984, p. 34.

E-mail:kostia.mamonov2017@gmail.com 